\title{
Influence of transcutaneous electrical stimulation on heterotopic ossification: an experimental study in Wistar rats
}

\author{
T.G.G. Zotz ${ }^{1}$ and J.B. de Paula ${ }^{2}$ \\ ${ }^{1}$ Departamento de Fisioterapia, Escola de Saúde e Biociências, Pontifícia Universidade Católica do Paraná, \\ Curitiba, PR, Brasil \\ ${ }^{2}$ Departamento de Medicina, Universidade Estadual de Ponta Grossa, Ponta Grossa, PR, Brasil
}

\begin{abstract}
Heterotopic ossification ( $\mathrm{HO})$ is a metaplastic biological process in which there is newly formed bone in soft tissues, resulting in joint mobility deficit and pain. Different treatment modalities have been tried to prevent HO development, but there is no consensus on a therapeutic approach. Since electrical stimulation is a widely used resource in physiotherapy practice to stimulate joint mobility, with analgesic and anti-inflammatory effects, its usefulness for HO treatment was investigated. We aimed to identify the influence of electrical stimulation on induced $\mathrm{HO}$ in Wistar rats. Thirty-six male rats (350-390 g) were used, and all animals were anesthetized for blood sampling before HO induction, to quantify the serum alkaline phosphatase. $\mathrm{HO}$ induction was performed by bone marrow implantation in both quadriceps of the animals, which were then divided into 3 groups: control (CG), transcutaneous electrical nerve stimulation (TENS) group (TG), and functional electrical stimulation (FES) group (FG) with 12 rats each. All animals were anesthetized and electrically stimulated twice per week, for 35 days from induction day. After this period, another blood sample was collected and quadriceps muscles were bilaterally removed for histological and calcium analysis and the rats were killed. Calcium levels in muscles showed significantly lower results when comparing TG and FG $(P<0.001)$ and between TG and CG $(P<0.001)$. Qualitative histological analyses confirmed $100 \% \mathrm{HO}$ in FG and CG, while in TG the $\mathrm{HO}$ was detected in $54.5 \%$ of the animals. The effects of the muscle contractions caused by FES increased $\mathrm{HO}$, while anti-inflammatory effects of TENS reduced HO.
\end{abstract}

Key words: Heterotopic ossification; Experimental model; Electrical stimulation; Functional electrical stimulation; Transcutaneous electrical nerve stimulation

\section{Introduction}

Since 1883, under certain pathological conditions, bone formation has been observed in extraskeletal tissues (1). This is called heterotopic or ectopic bone formation, considered as true bone, and contains all the morphological and metabolic bone tissue, including bone marrow (BM) (2). The formation of heterotopic bone may be due to muscle trauma (myositis ossificans) (3). It is common in people who have undergone total hip arthroplasty $(4,5)$, those with spinal cord injuries (6), and victims of head trauma $(7,8)$, all of which often lead to long periods of immobilization of the affected limbs.

About $10 \%$ of the cases are symptomatic heterotopic ossification $(\mathrm{HO})$, resulting in limitations in range of motion $(6,9)$. Although its etiology is not fully elucidated, it has been proven that its onset is associated with damage and inflammatory processes in soft tissue (9). Based on this information, various treatment modalities have been tried to control the development of $\mathrm{HO}$, but few have been effective in preventing it and not without inherent risks $(3,9)$. Considering the treatments used to promote analgesia and consequently improve range of motion, some physical therapy resources could be useful tools for $\mathrm{HO}$ prevention or treatment.

In this sense, the therapeutic use of electric currents is one of several resources used in physical therapy. Once modulated with appropriate parameters, these currents can act in several different roles such as analgesia, muscle contraction, improved local circulation, fluid drainage, toning or muscle relaxation, improved regeneration, and healing of tissue (10).

Correspondence: T.G.G. Zotz: <talita.gnoato@gmail.com>; J.B. de Paula: <josuebrugipaula@gmail.com> 
Among the different forms of these electrical current applications, two were selected because they help in the kinetic functional recovery of individuals, producing analgesia postoperatively and muscle contraction to prevent atrophy due to downtime: transcutaneous electrical nerve stimulation (TENS), used as an adjunct method of analgesia in postoperative patients (11), and functional electrical stimulation (FES), used to reduce healing time and prevent muscle atrophy in the spinal cord (12).

Although it has not been elucidated whether all the injurious effects of immobilization on the tissues can be completely reversed with remobilization techniques (13), it is known that electrical nerve stimulation may be a method of prophylactic and therapeutic treatment and may contribute to the regression or prevention of $\mathrm{HO}$. However, there is a need for further studies to verify those results (14).

Despite technological advances in relation to the effects of electric currents in physical therapy, the effects on $\mathrm{HO}$ are not known. To obtain such knowledge, it is necessary to use animal research to determine what happens in the body, with the purpose of contributing to a model that can be used in humans. Therefore, the aim of this research was to identify the influence of FES and TENS on $\mathrm{HO}$ in Wistar rats.

\section{Material and Methods}

\section{Sample}

An experimental, randomized, controlled and crosssectional study was conducted. This research was submitted to the CEUA (Ethics Committee of Animal Use) of the Pontifícia Universidade Católica do Paraná (\#499/09).

The animals were grouped into 9 standard plastic cages, each containing 4 animals, and they were numbered from one to four and maintained under controlled environmental conditions (12:12-h light-dark cycle), with free access to water and pelleted food. The study was conducted according to Federal regulation 11794/08 and the recommendations of the Brazilian College of Animal Experimentation (15).

Prior to the procedures described herein, all animals were anesthetized by intramuscular injections of $80 \mathrm{mg} / \mathrm{kg}$ ketamine and $8 \mathrm{mg} / \mathrm{kg}$ xylazine, receiving a booster dose, if necessary.

The first blood collection was from intracardiac puncture, 1 week before $\mathrm{HO}$ induction (16), giving the animals time to recover from the blood collection and any eventual blood loss. The experiment lasted 43 days: day 1 was the first blood collection, day 8 was $\mathrm{HO}$ induction, and day 43 was the day the animals were killed. The period between BM implantation and death was 35 days.

The sample consisted of 36 Rattus norvegicus (adult, albino, male Wistar), weighing 350-390 g. The size of the animals was essential to facilitate blood collection and placement of electrodes. The animals were randomly divided into 3 groups after $\mathrm{HO}$ induction as follows: control group (GC), subject only to the $\mathrm{HO}$ induction protocol $(n=12)$; FES group (FG), submitted to $\mathrm{HO}$ induction and FES protocols $(n=12)$; and TENS group (TG), submitted to $\mathrm{HO}$ induction and TENS protocols $(n=12)$.

The animals were identified by a numeric code marked on the tail (1 through 4 ), and the boxes were numbered 1 through 9 .

\section{$\mathrm{HO}$ induction method}

All animals were anesthetized by intramuscular injections of $80 \mathrm{mg} / \mathrm{kg}$ ketamine and $8 \mathrm{mg} / \mathrm{kg}$ xylazine, receiving a booster dose, if necessary. BM was collected bilaterally from the iliac crest of the animal with a $25 \times 17 \mathrm{~mm}$ puncture needle. After collection, BM was implanted bilaterally in the quadriceps. For the implant, a thin needle $(0.3 \times 16 \mathrm{~mm})$ for insulin injection was inserted perpendicularly to the ventral side of the thigh. All animal groups received $0.35 \mathrm{~mL}$ of $\mathrm{BM}$ and were given oral doses of $20 \mathrm{mg} \cdot \mathrm{kg}^{-1} \cdot 24 \mathrm{~h}^{-1}$ dipyrone $(500 \mathrm{mg} / \mathrm{mL}$, Eurofarma, Brazil) during the first 3 days for pain relief after the BM collection procedure (16).

\section{Electrical stimulation protocol}

A digital electrical stimulator (FES VIF 995, 4 channel; QUARK, Brazil) was used for quadriceps contraction. Before using the device, a test measurement $(17,18)$ was performed, using a digital Oscilloscope (Tecktronix THS $710 \mathrm{~A}$, USA) in real time, which was a portable batterypowered oscilloscope to avoid interference from external sources. The unit operated at constant current (70 mA). The duration of therapy was controlled by a stopwatch. Silicon-carbon electrodes with a 1-cm diameter circular shape were used, because they presented lower impedance when compared to self-adhesive electrodes. To evaluate the impedance of the electrodes, we used a Tektronix DMM 914 multimeter, which detected 17 Ohm for the silicon-carbon and $3 \mathrm{kOhm}$ for the self-adhesive electrode.

The electrodes were placed on the motor points as follows: one channel (two electrodes) was placed on the groin and one above the knee. The first was placed on the inguinal region, near the origin of the vastus medialis, and the second at a distance of $0.5 \mathrm{~cm}$ from the knee, with a distance of $2 \mathrm{~cm}$ between the electrodes. To improve the contact area of the electrodes with the skin, the animals were shaved in the hindquarters, and a gel layer was applied to protect the animal from burns and facilitate current conduction (19).

The parameters for the application of FES and TENS were defined from the calibration curves of the device in relation to the current amplitude, frequency, and duration of stimulation pulse parameters as determined for FES (Table 1) and TENS (Table 2).

The conventional TENS was applied to the sensory level. The intensity of the sensory level was determined by increasing this parameter up to the observation of muscle 
Table 1. Parameters for application of functional electrical stimulation (FES).

\begin{tabular}{lc}
\hline & FES parameters \\
\hline ON time (current uptime) & $6 \mathrm{~s}$ \\
OFF time (current idle time) & $12 \mathrm{~s}$ \\
Pulse frequency & $19.3 \pm 0.04 \mathrm{~Hz}$ \\
Rising pulse & $1 \mathrm{~s}$ \\
Sustain (maintenance pulse) & $5 \mathrm{~s}$ \\
Intensity & $3.1 \pm 0.12 \mathrm{~V}$ \\
Time of application & $30 \mathrm{~min}$ \\
Pulse duration & $238.5 \pm 5.1 \mu \mathrm{s}$ \\
\hline
\end{tabular}

contraction, when it was reduced below the level of contraction (20).

\section{Material collection}

The rats were anesthetized to collect blood samples for the measurement of alkaline phosphatase (ALP) and for the dissection of the left and right quadriceps. During dissection, the muscles were periodically applied with an isotonic saline drip to prevent tissue drying. Under anesthesia, death was induced with a lethal intracardiac dose of anesthetic. From each group, we collected 24 muscles for analysis, 12 for histological analysis, and 12 for spectrophotometric calcium measurement. The intracardiac blood for ALP determination was collected at day 1 and at day 43 (16).

Histological analysis. At the end of the experiment, all collected muscles were cut across the belly, on the region where the BM was implanted. Each half was again cut into 5-mm slices, leaving the muscle divided into four pieces. These four pieces were placed in paraffin and labeled. They were then sectioned into $8-\mu \mathrm{m}$ slices with an Olympus microtome (USA) for the preparation of histological slides. They were stained with hematoxylin and eosin and Mallory's trichrome. Each slide was microphotographed under 40,100, and $200 \times$ magnification and used to search for implantation tissues.

Spectrophotometer analysis. The analysis was performed to measure the calcium levels in the left quadriceps with a Spectr AA 250 Plus (Varian, USA) flame spectrophotometer. Before analysis, the sample was subjected to a liquefaction process $(21,22)$ in order to

Table 2. Parameters for application of transcutaneous electrical nerve stimulation (TENS).

\begin{tabular}{lc}
\hline & TENS parameters \\
\hline Pulse duration & $99.14 \pm 0.26 \mu \mathrm{s}$ \\
Pulse frequency & $98.27 \pm 0.05 \mathrm{~Hz}$ \\
Intensity & $3.1 \pm 0.12 \mathrm{~V}$ \\
Time of application & $20 \mathrm{~min}$ \\
\hline
\end{tabular}

produce a homogeneous sample of biological material. The spectrophotometer was calibrated, using the most intense emission line of calcium at $422.7 \mathrm{~nm}$.

\section{Statistical analysis}

The results are reported as mean, median, minimum, maximum, and standard deviation. Analysis of variance with one factor was used to compare the group results in weight variables. To evaluate the effect of time on the weight (pre $\times 8$ days $\times 43$ days), we used the model of variance analysis with repeated measures. Multiple comparisons were made by the least significant difference test. In relation to the ALP variable, a comparison between pre- and post-43 days was performed using Student's $t$-test for paired samples. The normal condition of the data was evaluated using the Shapiro-Wilks test. $P$ values less than 0.05 were considered to be statistically significant. Data were analyzed with the computer program Statistica v.8.0 (USA).

\section{Results}

The study began with 36 animals divided into 3 groups, but 5 died before the end of the study, and 31 animals were left for final analysis. There were 2 losses in FG and CG, and one in TG. There was a weight gain within each group (Figure 1). Figure 1 illustrates the evolution of the mean weight of the animals, standard deviations (rectangles), and maximum and minimum values (vertical lines) for each group.

In the evaluation of ALP on day 43, there were significant differences between the averages of the three groups. Note that ALP was significantly lower in group TG than in group $F G$ at day $43(P=0.011$; Figure 2).

When comparing the amount of calcium in the quadriceps muscle between groups, there were statistically significant lower results for group TG compared to groups $F G$ and $C G(P<0.001$; Figure 3$)$.

A qualitative histological analysis was performed to evaluate the presence of heterotopic bone formation in the muscle tissues. There was $\mathrm{HO}$ in all animals of $\mathrm{FG}$ and CG, and only 7 of 11 animals showed heterotopic bone formation in TG (Figure 4).

\section{Discussion}

It is known that $\mathrm{HO}$ is a condition that can lead to a decreased range of motion, and can even cause pain when there is no loss of sensitivity $(6,23)$. The most commonly affected site is skeletal muscle (24). According to Uezumi et al. (24), skeletal muscle serves as a physical safeguard for the other organs and is anatomically located immediately beneath the skin, so it represents the most damaged organ in the body. Although skeletal muscle is characterized by the presence of fatty and connective tissues that originated from nonmyogenic mesenchymal 


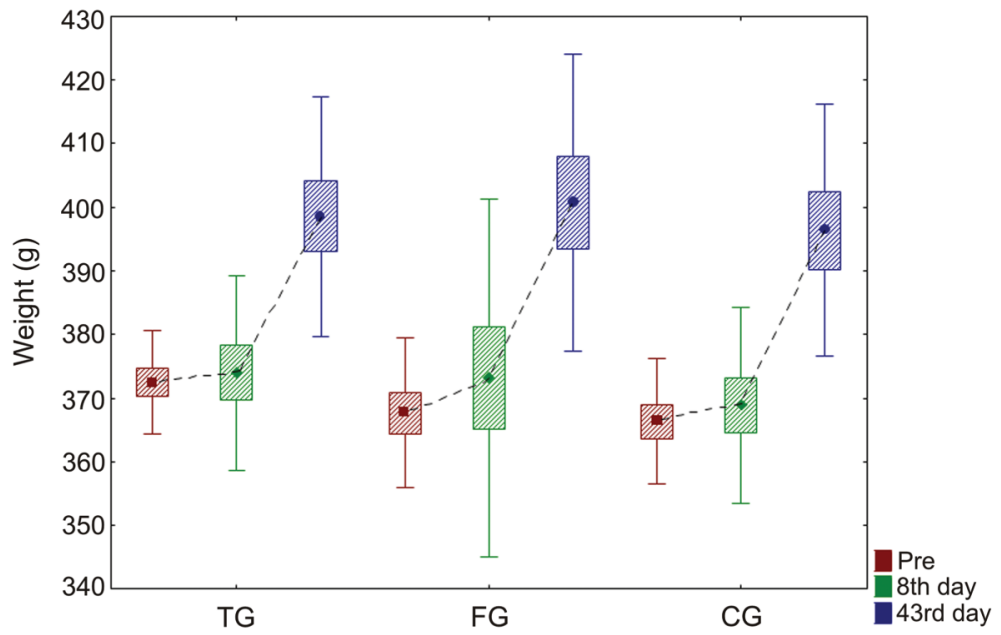

Figure 1. Comparison of weight within each group. Data are reported as averages, standard deviation and maximum and minimum errors. CG: control group; TG: transcutaneous electrical nerve stimulation (TENS) group; FG: functional electrical stimulation (FES) group. ANOVA was used for statistical analysis $(P>0.05)$.

progenitors, those progenitors were initially identified in BM (25). Therefore, HO has been thought to result from inappropriate differentiation of progenitor cells, induced by a pathological imbalance of local or systemic factors (24).

In this study, the mechanism used to experimentally induce $\mathrm{HO}$ formation was based on the presence of mesenchymal progenitors in BM that was collected and introduced into skeletal muscle of rats.

In addition to the concern about the mechanisms of heterotopic bone formation, the careful choice of treatment is important. Several forms of treatment are proposed to prevent or combat the development of heterotopic bone, but many have unwanted side effects $(26,27)$.

Some physical therapy techniques can be even worse than $\mathrm{HO}(7,26)$. When there is no sensitivity in the patient, even passive movements can cause limb tissue shear, triggering a local inflammatory reaction, which can aggravate $\mathrm{HO}$ when present, or unleash it.

Therefore, this study tested the use of electrical stimulation for $\mathrm{HO}$. This therapy is suitable for improving range of motion and decreasing pain $(27,28)$. When applied with the appropriate parameters, the treatment is effective.

When the goal is to gain muscle contraction, Arantes et al. (29) reported that FES is better suited to induce action potentials in the motor nerve, causing activation of motor units. According to Rushton (30), TENS is one of the main therapeutic electrical currents used in acute and chronic pain conditions. This treatment has been used extensively in healthcare centers for the symptomatic management of acute and chronic pain of benign origin, and also in the palliative care of pain caused by metastatic bone diseases and neoplasms (31).

This research proposed to apply FES and TENS stimulation to determine their influence on induced $\mathrm{HO}$ in Wistar rats. A common result of that stimulation, verified in animal studies, specifically in rats, is weight loss. In this study, despite the stress of the handling and anesthesia procedures, there was a weight gain in most animals. It can be inferred that, despite the constant manipulation

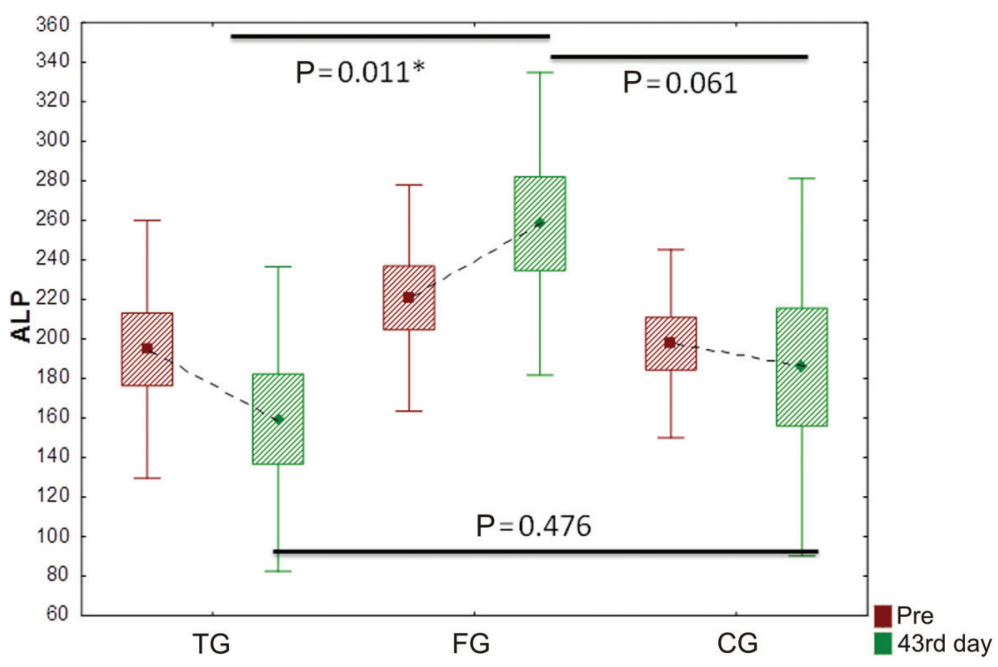

Figure 2. Comparison of alkaline phosphatase (ALP) among groups. Data are reported as averages, standard deviation and maximum and minimum errors. TG: transcutaneous electrical nerve stimulation (TENS) group; FG: functional electrical stimulation (FES) group; CG: control group. Student's $t$-test was used for statistical analysis $\left({ }^{*} \mathrm{P}<0.05\right)$. 


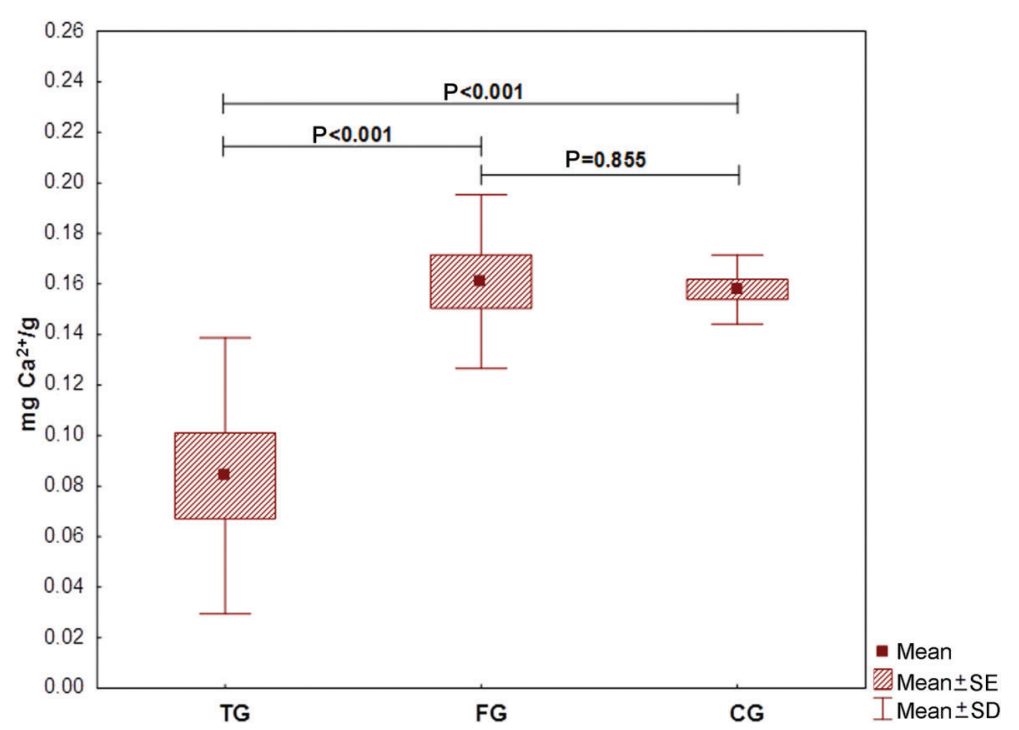

Figure 3. Comparison of the amount of calcium among groups. Data are reported as averages, standard deviation and maximum and minimum errors. TG: transcutaneous electrical nerve stimulation (TENS) group; FG: functional electrical stimulation (FES) group; CG: control group. The LSD test was used for statistical analysis $(P<0.05)$.

and anesthesia of the animals in this study, there was no significant interference to cause a loss of weight $(32,33)$.

By comparing the behavior of the variable ALP between groups, it was observed that, at the beginning of the study, all groups were equal. On day 43, CG and TG showed mean value gains, whereas FG showed increased levels of ALP, which showed statistically significant differences when compared to FG and TG.

It is known that the examination of bone ALP is specific to assess osteoblast differentiation and mineralization increases as bone ALP values decrease, which leads to an increase in osteocalcin, a specific biochemical marker for bone formation (34). Despite the specificity of these tests, this research used ALP, because it is a tracer of osteoblast activity and also has been indicated as a diagnostic method for $\mathrm{HO}$ (35). However, it is known that, besides being present in bone, ALP is also present in the intestine, liver, kidneys, and placenta. Despite its presence in these organs, the increase in concentration may be related to the increase in the amount of calcium in the joints and muscles (35). The results showed a $97.5 \%$ specificity to detect bone activity (35).

The evaluation of calcium concentration in the muscles was performed by flame spectrophotometry. To this end, the muscles were weighed to calculate the amount of calcium per gram of muscle. In the case of heterotopic bone presence, the muscles would be heavier; however, this was not detected. The levels of calcium were statistically lower when comparing TG with FG or CG.

Muscle contraction occurs by the deposition of calcium in muscle tissue, and this stimulates the sliding of actin and myosin myofibrils, which characterizes the contractile process (36). In this research, this contractile process was generated artificially by electrical stimulations in the parameters of FES. It could be said that the increased levels of ALP in FG, and no significant difference in calcium concentration in TG, are related to the artificially stimulated muscle contractions in FG. This generated an increase in the number of contractions and increased local blood flow and deposition of calcium in the region of BM implantation, which may have contributed to the process of heterotopic bone formation. An explanation for the means by which FES stimulated $\mathrm{HO}$ formation is that electrical stimulation, when applied at the level of motor threshold in regions of bone fracture, promotes increased local vascular permeability in the BM and is related to the process of ossification (37). According to ljiri et al. (37), electrical stimulation helps the deposition of calcium, causes changes in oxygen content and $\mathrm{pH}$, stimulates expression of growth factors, and recruits help in osteoblast migration and secretion of extracellular matrix (ECM), leading to bone formation.

Mechanotransduction refers to the process by which the body converts a mechanical stimulus into a cellular response $(33,36)$. This cellular response promotes structural changes in muscle. Physical exercise or electrical stimulation act as a mechanical stimulus (37), which promotes a physical disturbance to the cells, which is transformed into a variety of chemical signals intra- and extracellularly. The mechanical stimulus generated is transmitted to the muscle fiber through ECM, passing by the sarcolemma, and reaching intracellular molecules and the contractile system $(33,36)$. In this sense, it is believed that different parameters of electrical stimulation can cause different results, as verified in this study.

We found a reduction in ALP and muscle calcium levels in TG. Because this form of stimulation has an antiinflammatory action (38), the inflammatory process generated by the BM implant possibly regressed after TENS application. Moreover, the endogenous opioids 


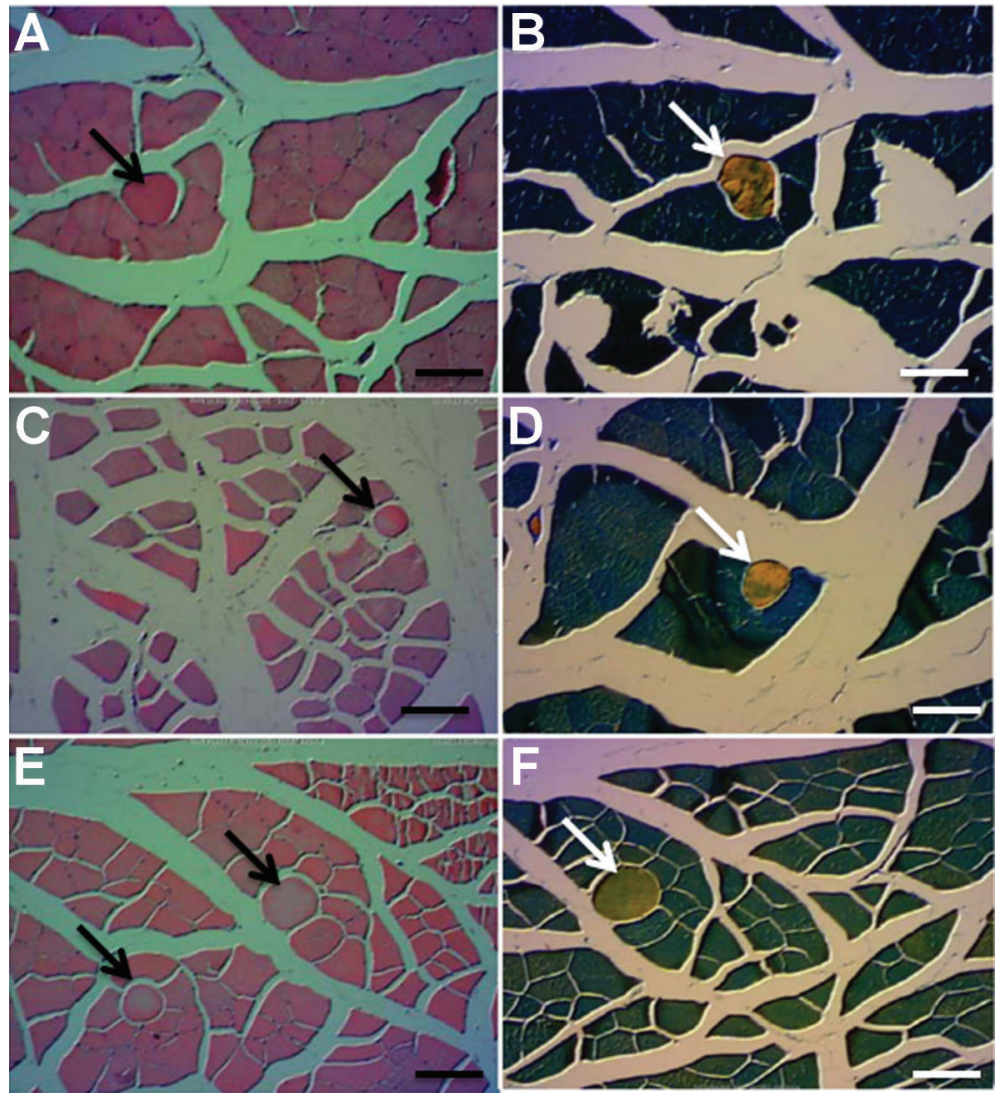

Figure 4. A, Control group, presence of heterotopic ossification (arrow) stained with hematoxylin and eosin (HE). B, Control group, confirmation of heterotopic bone formation (arrow) with Mallory's trichrome. C, Functional electrical stimulation (FES) group, presence of heterotopic ossification (arrow) stained with HE. D, FES group, confirmation of heterotopic bone formation (arrow) with Mallory's trichrome. E, Transcutaneous electrical nerve stimulation (TENS) group, presence of heterotopic ossification (arrow) stained with HE. $F$, TENS group, confirmation of heterotopic bone formation (arrow) with Mallory's trichrome. Scale bars $=100 \mu \mathrm{m}$.

released by the TENS application reduce the deposition of calcium in the muscle tissues during this stimulation (39). Gopalkrishnan and Sluka (40) compared the high frequency of TENS application $(100 \mathrm{HZ})$ and low frequency $(4 \mathrm{~Hz})$ with different pulse durations (100 and $200 \mu \mathrm{s}$ ) for $20 \mathrm{~min}$, in rats subjected to induction of the inflammatory process on their paws. They verified that the TENS of high frequency with a pulse duration of $100 \mu$ s significantly reduced the inflammatory process and pain in animals.

Thus, the process of heterotopic bone formation may have been delayed in some animals. In CG, there was a slight decrease in the ALP levels, and, comparing this group with $F G$, there was a statistically significant difference showing that FG presented higher levels of ALP.

The literature reports that an accommodation stimulus normally occurs, and this may undermine the expected effects of the treatments. Therefore, it is necessary to increase the current intensity or change other parameters to continue generating a sufficient stimulus (37). This did not occur in this study. Independent of stimulation, the parameters remained the same from start to finish.

For the visualization of bone formation, histological analysis was chosen, because the volumes of BM implant bone formation were small, and would be difficult to see in conventional radiography. Radiographic findings of experimental research with small volumes of implant can prove to be difficult to visualize bone formation. Some opacity, when viewed radiographically, can be inconclusive as to whether it is bone tissue resulting from edema or simply implant material that induces $\mathrm{HO}$. Although the analysis of ALP and calcium levels showed a decrease in TG, bone formation was confirmed by histology in $54.5 \%$ of the animals in this group (6 of 11). FG and CG showed bone formation in $100 \%$ of the animals.

In studies using implants into the quadriceps of rabbit BM (3), new bone formation was seen in CG and the groups using anti-inflammatory agents. As far as it is known, this is the first study that verifies the influence of electrical stimulation on induced $\mathrm{HO}$.

As a suggestion for future work, it would be of interest to monitor the effects of stimulation at 7, 14, 21, and 35 days, and even longer times $(60,90$, and 120 days), in order to visualize the evolution of the BM implant. Another line of research that is needed would be to compare different parameters of electrical stimulation on $\mathrm{HO}$, so that the indication for the use of this resource becomes safe and evidence based.

Whereas FES promotes muscle contractions, which consequently increases the local blood flow and promotes increased secretion of extracellular matrix, it was found that the influence of FES with a frequency-modulated 
stimulation of $19.3 \pm 0.04 \mathrm{~Hz}$ (pulse duration 238.5 \pm $5.1 \mu \mathrm{s}, 6 \mathrm{~s}$ on time, $12 \mathrm{~s}$ off time, magnitude of stimulation $3.1 \pm 0.12 \mathrm{~V}, 30 \mathrm{~min}$ duration) showed enhanced effects on heterotopic bone formation.

On the other hand, the anti-inflammatory effect of TENS with a frequency-modulated stimulation of

\section{References}

1. Gautschi OP, Cadosch D, Bauer S, Filgueira L, Zellweger R. [Heterotopic ossification - from the aetiology to the current management]. Unfallchirurg 2008; 111: 523-534, doi: 10.1007/ s00113-008-1475-z.

2. Balboni TA, Gobezie R, Mamon HJ. Heterotopic ossification: Pathophysiology, clinical features, and the role of radiotherapy for prophylaxis. Int J Radiat Oncol Biol Phys 2006; 65: 1289-1299, doi: 10.1016/j.jijobp.2006.03.053.

3. Namazi H, Mozaffarian K. Levothyroxin inhibits heterotopic ossification: an experimental study in rabbits. J Trauma 2008; 65: 849-851.

4. Castro AW, Greve JM. Ossificação heterotópica em pacientes com lesão medular traumática: associação com antígenos do sistema HLA. Acta Ortop Bras 2003; 11: 102-109, doi: 10.1590/S1413-78522003000200006.

5. Kocic M, Lazovic M, Mitkovic M, Djokic B. Clinical significance of the heterotopic ossification after total hip arthroplasty. Orthopedics 2010; 33: 16, doi: 10.3928/01477447-20091124-13.

6. Araújo IF, Taricco LD, Cruz CL, Ares MJ, Cristante ARL. Ossificação heterotópica em pacientes neurológicos: atualizando conceitos. Med Reabil 2008; 27: 89-92.

7. Linan E, O'Dell MW, Pierce JM. Continuous passive motion in the management of heterotopic ossification in a brain injured patient. Am J Phys Med Rehabil 2001; 80: 614-617, doi: 10.1097/00002060-200108000-00013.

8. Espandar R, Haghpanah B. Acceptable outcome following resection of bilateral large popliteal space heterotopic ossification masses in a spinal cord injured patient: a case report. J Orthop Surg Res 2010; 5: 39, doi: 10.1186/1749799X-5-39.

9. Kan L, Kessler JA. Animal models of typical heterotopic ossification. J Biomed Biotechnol 2011; 2011: 309287.

10. Starkey C. Recursos terapêuticos em fisioterapia.1st edn. São Paulo: Manole; 2015

11. Reeves JL, Graff-Radford SB, Shipman D. The effects of transcutaneous electrical nerve stimulation on experimental pain and sympathetic nervous system response. Pain Med 2004; 5: 150-161, doi: 10.1111/pme.2004.5.issue-2.

12. Durigan JLQ, Cancelliero KM, Polacow MLO, Silva CA, Guirro RRJ. Modelos de desuso muscular e estimulação elétrica neuromuscular: aspectos pertinentes à reabilitação fisioterapêutica. Fisioter Mov 2005; 18: 53-62.

13. Andrews JR, Harrelson GL, Wilk KE. Reabilitação física das lesões desportivas. Rio de Janeiro: Guanabara Koogan; 2000.

14. Ferreira DBJ, Lippelt HC, Cliquet JR. A estimulação elétrica neuromuscular na reversão da ossificação heterotópica. Acta Ortop Bras 2006; 14: 72-74, doi: 10.1590/S141378522006000200002.

15. Sociedade Brasileira de Ciência em Animais de Laboratório. Informação Técnica, Animal Welfare Information Center. http://www.cobea.org.br/. Accessed November 23, 2009.
$98.27 \pm 0.05 \mathrm{~Hz}$ (pulse duration $99.14 \pm 0.26 \mu \mathrm{s}$, range of current $3.1 \pm 0.12 \mathrm{~V}$, and $20 \mathrm{~min}$ duration) showed inhibitory effects on experimental heterotopic bone formation.

Thus, the application of calcium nerve stimulation using TENS appears to be a viable treatment option for $\mathrm{HO}$.

16. Zotz TG, Paula JB, Moser AD. Experimental model of heterotopic ossification in Wistar rats. Braz J Med Biol Res 2012; 45: 497-501, doi: 10.1590/S0100-879X2012007500049.

17. Gnoato TG, Paula JB. Influência da estimulação elétrica transcutânea sobre a ossificação heterotópica: estudo esperimental em ratos. [Master's thesis]. Curitiba: Pontiícia Universidade Católica do Paraná; 2011.

18. Morales RC. Proposta de ensaios e avaliação de estimuladores elétricos neuromusculares. [Master's thesis]. Curitiba: Universidade Tecnológica do Paraná; 2004.

19. Matheus JP, Gomide LB, Oliveira JG, Volpon JB, Shirmano AC. Efeitos da estimulação elétrica neuromuscular durante a imobilização, nas propriedades mecânicas do músculo esquelético. Rev Bras Med Esporte 2007; 14: 55-59.

20. Hingne PM, Sluka KA. Blockade of NMDA receptors prevents analgesic tolerance to repeated transcutaneous electrical nerve stimulation (TENS) in rats. J Pain 2008; 9: 217-225.

21. Carasek E, Tonjes J, Scharf M. Pré-concentração de chumbo e cádmio em um sistema de micro extração líquido-líquido e determinação por espectrometria de absorção atômica com chama. Quim Nova 2002; 25: 748-752, doi: 10.1590/S010040422002000500008.

22. Okumura F, Cavalheiro E, Nóbrega J. Experimentos simples usando fotometria de chama para ensino de princípios de espectrofotometria atômica em cursos de química analítica. Quím Nova 2004; 27: 832-836.

23. Zeilig G, Weingarden HP, Levy R, Peer I, Ohry A, Blumen N. Heterotopic ossification in Guillain-Barre syndrome: incidence and effects on functional outcome with long-term follow-up. Arch Phys Med Rehabil 2006; 87: 92-95, doi: 10.1016/j.apmr.2005.07.308.

24. Uezumi A, Ikemoto-Uezumi M, Tsuchida K. Roles of nonmyogenic mesenchymal progenitors in pathogenesis and regeneration of skeletal muscle. Front Physiol 2014; 5 : 68, doi: 10.3389/fphys.2014.00068.

25. Uezumi A, Fukada S, Yamamoto N, Takeda S, Tsuchida K. Mesenchymal progenitors distinct from satellite cells contribute to ectopic fat cell formation in skeletal muscle. Nat Cell Biol 2010; 12: 143-152, doi: 10.1038/ncb2014.

26. Vanden Bossche L, Vanderstraeten G. Heterotopic ossification: a review. J Rehabil Med 2005; 37: 129-136, doi: 10.1080/16501970510027628.

27. Kesar TM, Perumal R, Jancosko A, Reisman DS, Rudolph KS, Higginson JS, et al. Novel patterns of functional electrical stimulation have an immediate effect on dorsiflexor muscle function during gait for people poststroke. Phys Ther 2010; 90: 55-66, doi: 10.2522/ptj.20090140.

28. Riccin NA, Dias CN, Driusso P. A utilização de recursos eletrotermofototerapêuticos no tratamento da Síndrome da Fibromialgia: uma revisão sistemática. Rev Bras Fisioter 2010; 14: 1-9, doi: 10.1590/S1413-35552010000100002. 
29. Arantes NF, Vaz DV, Mancini MC, Pereira MS, Pinto FP, Pinto TP. Efeitos da estimulação elétrica funcional nos músculos do punho e dedos em indivíduos hemiparéticos: uma revisão sistemática da literatura. Rev Bras Fisioter 2007; 11: 419-427, doi: 10.1590/S1413-35552007000600002.

30. Rushton DN. Electrical stimulation in the treatment of pain. Disabil Rehabil 2002; 24: 407-415, doi: 10.1080/ 09638280110108832.

31. Brousseau L, Yonge K, Marghand S, Shea B, Wells GI. Efficacy of transcutaneous electrical nerve stimulation for osteoarthritis of the lower extremities: a meta-analysis. Phys Ther Rev 2004; 9: 213-233, doi: 10.1179/108331904225007069.

32. Balcombe JP, Barnard ND, Sandusky C. Laboratory routines cause animal stress. Contemp Top Lab Anim Sci 2004; 43: 42-51.

33. Gomes AR, Coutinho EL, Franca CN, Polonio J, Salvini TF. Effect of one stretch a week applied to the immobilized soleus muscle on rat muscle fiber morphology. Braz $\mathrm{J}$ Med Biol Res 2004; 37: 1473-1480, doi: 10.1590/S0100879X2004001000005.

34. Ratisoontorn C, Seto ML, Broughton KM, Cunningham ML. In vitro differentiation profile of osteoblasts derived from patients with Saethre-Chotzen syndrome. Bone 2005; 36: 627-634.
35. Shehab D, Elgazzar AH, Collier BD. Heterotopic ossification. J Nuclear Med 2003; 43: 346-353.

36. Guyton AC, Hall JE. Fundamentos de Guyton - tratado de fisiologia médica.Rio de Janeiro: Guanabara Koogan; 2002.

37. Ijiri K, Matsunaga S, Fukuda T, Shimizu T. Indomethacin inhibition of ossification induced by direct current stimulation. J Orthop Res 1995; 13: 123-131, doi: 10.1002/(ISSN) 1554-527X.

38. Vance CG, Radhakrishnan $R$, Skyba DA, Sluka KA. Transcutaneous electrical nerve stimulation at both high and low frequencies reduces primary hyperalgesia in rats with joint inflammation in a time-dependent manner. Phys Ther 2007; 87: 44-51, doi: 10.2522/ptj.20060032.

39. Motta MA, Vasconcelos MS, Catanho MT. Antinociceptive action of captopril and transcutaneous electric nerve stimulation in Mus musculus mice. Clin Exp Pharmacol Physiol 2002; 29: 464-466, doi: 10.1046/j.1440-1681. 2002.03669.x.

40. Gopalkrishnan P, Sluka KA. Effect of varying frequency, intensity, and pulse duration of transcutaneous electrical nerve stimulation on primary hyperalgesia in inflamed rats. Arch Phys Med Rehabil 2000; 81: 984-990, doi: 10.1053/ apmr.2000.5576. 